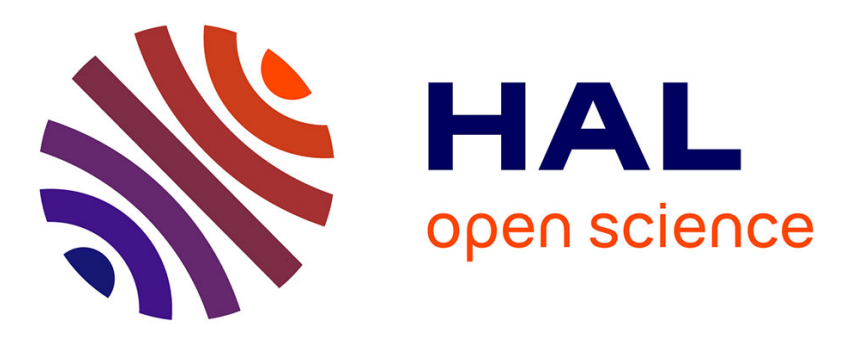

\title{
Phase Transformations of Metallorganic Chemical Vapor Deposition Processed Alumina Coatings Investigated by In Situ Deflection
}

\author{
Anne-Marie Huntz, Michel Andrieux, Constantin Vahlas, Maria-Magdalena \\ Sovar, Diane Samélor, Alain Gleizes
}

\section{To cite this version:}

Anne-Marie Huntz, Michel Andrieux, Constantin Vahlas, Maria-Magdalena Sovar, Diane Samélor, et al.. Phase Transformations of Metallorganic Chemical Vapor Deposition Processed Alumina Coatings Investigated by In Situ Deflection. Journal of The Electrochemical Society, 2007, vol. 154 (5), pp. 63-68. 10.1149/1.2715314. hal-00806108

\section{HAL Id: hal-00806108 https://hal.science/hal-00806108}

Submitted on 29 Mar 2013

HAL is a multi-disciplinary open access archive for the deposit and dissemination of scientific research documents, whether they are published or not. The documents may come from teaching and research institutions in France or abroad, or from public or private research centers.
L'archive ouverte pluridisciplinaire HAL, est destinée au dépôt et à la diffusion de documents scientifiques de niveau recherche, publiés ou non, émanant des établissements d'enseignement et de recherche français ou étrangers, des laboratoires publics ou privés. 


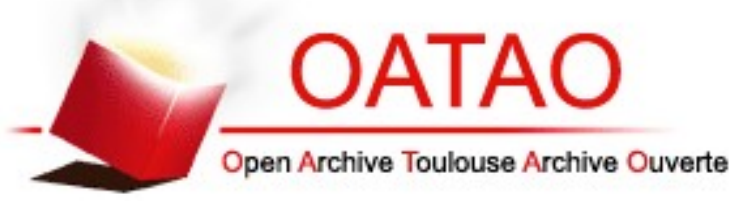

\section{Open Archive Toulouse Archive Ouverte (OATAO)}

OATAO is an open access repository that collects the work of Toulouse researchers and makes it freely available over the web where possible.

This is an author-deposited version published in: http://oatao.univ-toulouse.fr/ Eprints ID : 2435

To link to this article :

URL : http://dx.doi.org/10.1149/1.2715314

To cite this version : Huntz, Anne-Marie and Andrieux, Michel and Vahlas, Constantin and Sovar, Maria-Magdalena and Samélor, D. and Gleizes, Alain ( 2007) Phase Transformations of Metallorganic Chemical Vapor Deposition Processed Alumina Coatings Investigated by In Situ Deflection. Journal of The Electrochemical Society (JES), vol. 154 (n 5). pp. 63-68. ISSN 0013-4651

Any correspondence concerning this service should be sent to the repository administrator:staff-oatao@inp-toulouse.fr 


\title{
Phase Transformations of Metallorganic Chemical Vapor Deposition Processed Alumina Coatings Investigated by In Situ Deflection
}

\author{
Anne-Marie Huntz, ${ }^{\mathrm{a}, \mathrm{z}}$ Michel Andrieux,${ }^{\mathrm{a}}$ Constantin Vahlas, ${ }^{\mathrm{b}, *}$ \\ Maria-Magdalena Sovar, ${ }^{\mathrm{b}}$ Diane Samelor, ${ }^{\mathrm{b}}$ and Alain N. Gleizes ${ }^{\mathrm{b}}$ \\ ${ }^{a}$ Laboratoire d'Etude des Matériaux Hors Equilibre, CNRS-ICMMO, UMR 8182, Université Paris XI, \\ Centre d'Orsay, Bâtiment 410, 91405 Orsay, France \\ ${ }^{b}$ Centre Interuniversitaire de Recherche et d'Ingénierie des Matériaux (CIRIMAT), UMR 5085 CNRS, \\ ENSIACET, 31077 Toulouse Cedex 4, France
}

\begin{abstract}
Phase transformations of $\mathrm{Al}_{2} \mathrm{O}_{3}$ films, deposited by metallorganic chemical vapor deposition from aluminium tri-isopropoxide on AISI 301 stainless steel, were investigated using an original technique of deflection associated with X-ray diffraction and electron microscopy. The samples were first oxidized at $1123 \mathrm{~K}$ in air to obtain a $0.9 \mu \mathrm{m}$ thick $\mathrm{Cr}_{2} \mathrm{O}_{3}$ protective oxide film on one side of the samples. Then, $1 \mu \mathrm{m}$ thick amorphous $\mathrm{Al}_{2} \mathrm{O}_{3}$ films were deposited on the opposite side at $823 \mathrm{~K}$ and $2 \mathrm{kPa}$. The deflection of such dissymmetrical samples was recorded during anisothermal treatments, consisting in slow heating to $1173 \mathrm{~K}$ in $\mathrm{Ar}$ atmosphere. The coefficient of thermal expansion of both the $\mathrm{Cr}_{2} \mathrm{O}_{3}$ and the amorphous $\mathrm{Al}_{2} \mathrm{O}_{3}$ films was determined to be 7 $\times 10^{-6} \mathrm{~K}^{-1}$ and $14.7 \times 10^{-6} \mathrm{~K}^{-1}$, respectively. Crystallization kinetics of amorphous to mainly $\gamma-\mathrm{Al}_{2} \mathrm{O}_{3}$ become significant at temperatures equal or greater than $983 \mathrm{~K}$. Transformation of metastable $\mathrm{Al}_{2} \mathrm{O}_{3}$ to $\alpha-\mathrm{Al}_{2} \mathrm{O}_{3}$ is initiated below $1173 \mathrm{~K}$. It is demonstrated that deflection is a powerful tool for investigating the behavior of thin films deposited on a substrate and especially to reveal transformations occurring in these films during heat-treatments.
\end{abstract}

DOI: $10.1149 / 1.2715314$

Alumina coatings are used in various industrial applications due to their numerous allotropic forms. $\kappa$ and $\alpha$ forms are usually employed in microelectronics or as thermal barriers or hard coatings whereas $\gamma-\mathrm{Al}_{2} \mathrm{O}_{3}$, which presents high specific surface area when processed, forms liquid routes is used for supported catalysts. ${ }^{1-3}$ Such films are well-known to present allotropic transformations depending on the processing temperature or on postdeposition heattreatments. Metallorganic chemical vapor deposition (MOCVD) processed alumina films are often amorphous. ${ }^{4,5}$ According to the precursor used and to the processing conditions, mainly temperature, such films can contain hydroxyl $(\mathrm{OH})$ groups. Thus, during further heating, dehydration can occur, followed by crystallization with several possible crystallized phases according to parameters such as temperature, impurities, and annealing conditions. Such sequences of transformations have been illustrated by Castel and Frémy et al. ${ }^{6}$ They induce volume and thermal expansion variations in the film due to the different values of the molar volume and of the thermal expansion coefficient of the involved phases.

With the aim to detect and to investigate phenomena associated with such phase transformations, an original deflection technique, initially reported by Huntz et al., ${ }^{7}$ was applied in the present paper to MOCVD alumina films processed on AISI 301 stainless steel. It is shown hereafter that this technique allows determining in situ strain associated with any volume change in the sample due to various reasons such as differences in the thermal expansion coefficients of the films, or any phase transformation such as crystallization and allotropic transformations of the alumina film.

\section{Principle of Deflection}

Figure 1 presents a photograph of the deflection apparatus. It makes use of in situ optical recording of the curvature of a thin sample with a sensitivity of $\pm 5 \mu \mathrm{m}$. The optical recording is made via a charge-coupled device (CCD) camera positioned before a hole made on the furnace and connected to a PC. Another hole on one side of the furnace allows increasing the luminosity with a halogen lamp.

Two types of experiments, schematically illustrated in Fig. 2 can be done with this setup. In the first, which is shown on the left side

\footnotetext{
Electrochemical Society Active Member

${ }^{\mathrm{z}}$ E-mail: AM.huntz@lemhe.u-psud.fr
}

of the figure, symmetrical samples can be heat-treated in a corrosive atmosphere. In this case, compressive stresses develop in the corrosion products on all faces of the sample and can induce elongation of the underlying substrate. This elongation is added to the thermal expansion and experiments in inert atmosphere must be performed to separate the two phenomena. In the second type of experiment, illustrated on the right side of Fig. 2, the sample is dissymmetrical, and any volumetric variation on one large side will induce dissymmetrical stresses and thus curvature of the sample. This configuration corresponds to a sample with either a bare face or a coating whose characteristics are to be investigated on one large side and a protective film on the other. In the former case, during heating, an oxide film grows on the bare face and induces compressive stresses due to the higher molar volume of the oxide compared with that of the metal from which the oxide grows. In Fig. 2 the sample curves toward the right and, by convention, the deflection will be noted positively. The deflection mode is more sensitive than the elongation mode. Indeed, in case of elongation $d l=\varepsilon L \sim(\sigma / E) L, L$ being the

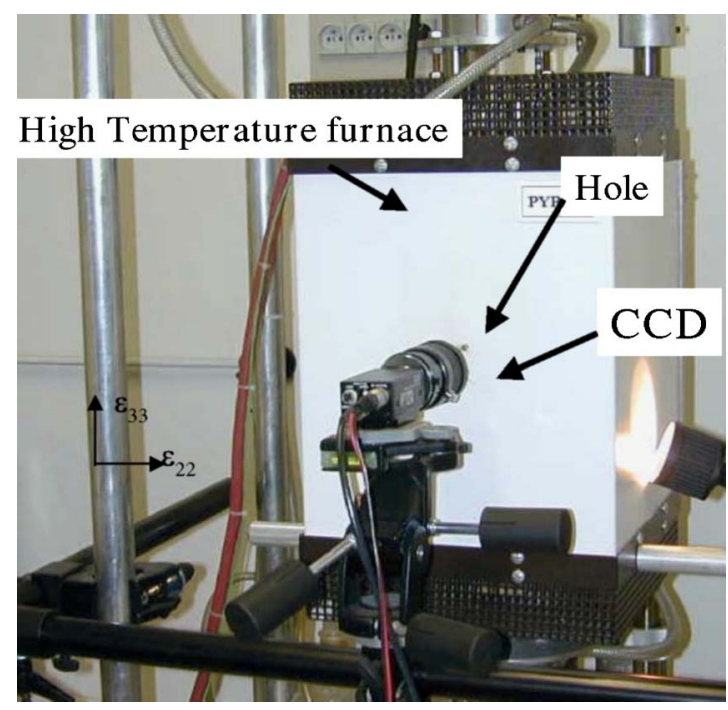

Figure 1. (Color online) Photograph of the setup used for the deflection experiments. 


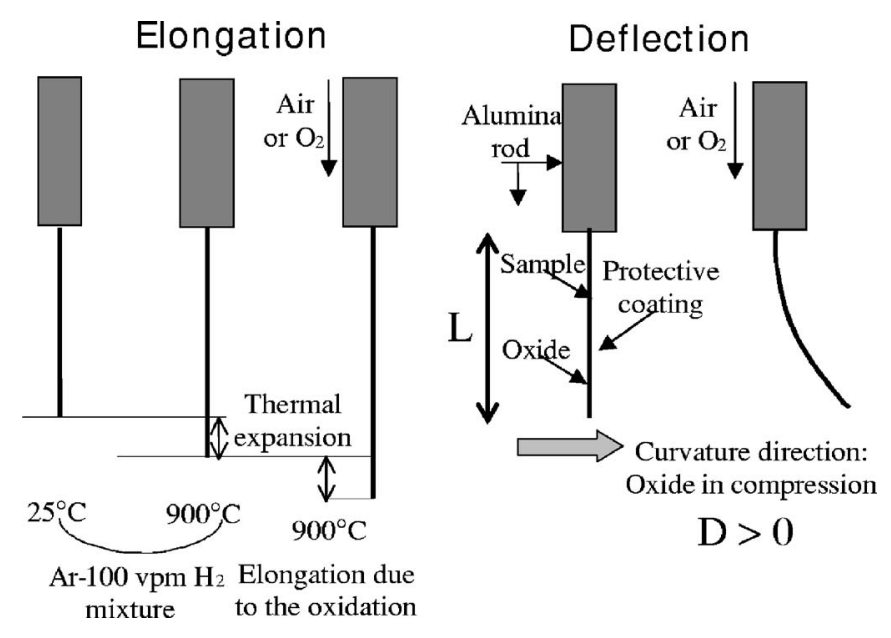

Figure 2. Principle of deflection experiments and conventional notation.

length of the sample, while in the case of deflection $D \sim(\sigma / E)$ $x\left(3 e_{\mathrm{f}} L^{2}\right) /\left(e_{\mathrm{m}}\right)^{2}, e_{\mathrm{f}}$ and $e_{\mathrm{m}}$ being the thickness of the film and of the metallic substrate, respectively. Therefore, in the first case the term $(\sigma / E)$ is multiplied by 40 , while, in the second case, it is multiplied by 120 .

\section{Experimental}

Dimensions of the deflection samples were $40 \times 8 \times 0.2 \mathrm{~mm}$. They were made from AISI 301 austenitic stainless steel (SS) containing 17 wt $\% \mathrm{Cr}, 7$ wt $\% \mathrm{Ni}, 2$ wt $\% \mathrm{Mn}, 1$ wt $\% \mathrm{Si}, 0.15$ wt $\%$ $\mathrm{C}$, and smaller quantities of phosphorous and sulfur. To protect one of the large sides of the sample and to avoid any contribution to the deflection behavior from undesired oxidation of the bare substrate due to the residual oxygen in the setup, a $30 \mathrm{~nm}$ thick, amorphous $\mathrm{Si}_{3} \mathrm{~N}_{4}$ film was initially processed by low-frequency plasmaenhanced CVD (PECVD) from $\mathrm{SiH}_{4}$ and $\mathrm{NH}_{3}$. However, after a heat-treatment corresponding to the deflection cycle, $\mathrm{Cr}_{2} \mathrm{O}_{3}$ was formed due to the oxidation of the underlying steel, was expanded, and covered the nitride surface. Spalling of the film was also observed. For these reasons, the $\mathrm{Si}_{3} \mathrm{~N}_{4}$ film was not considered a protective barrier. Alternatively, a $\mathrm{Cr}_{2} \mathrm{O}_{3}$ layer thermally grown by oxidation in air on the surface of the AISI 301 sample was investigated

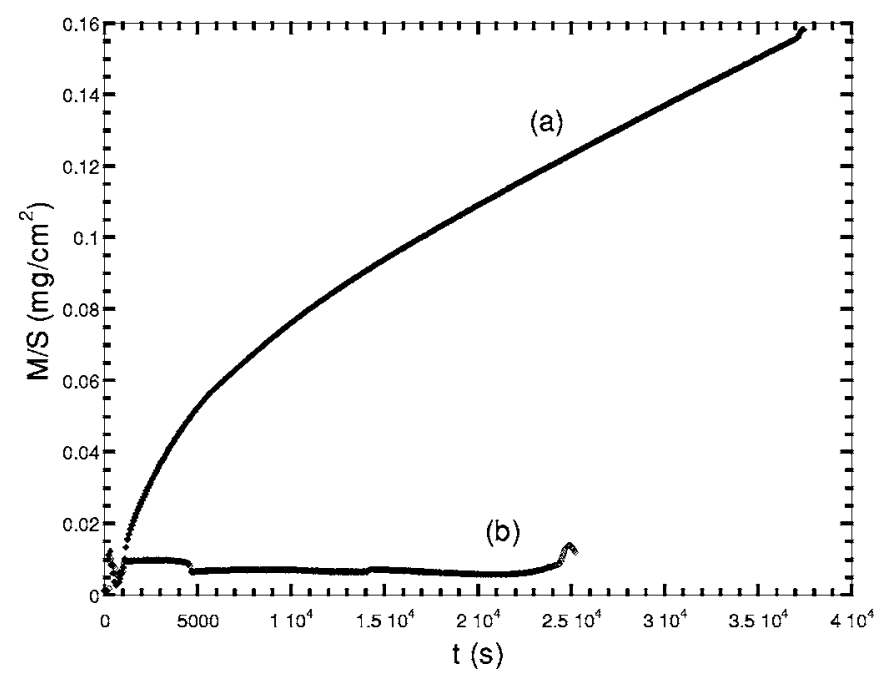

Figure 3. Weight gain per unit surface vs time of the AISI 301 SS. (a) Initial oxidation in laboratory air at $1123 \mathrm{~K}$ and (b) subsequent maintain at $1173 \mathrm{~K}$ in Ar.

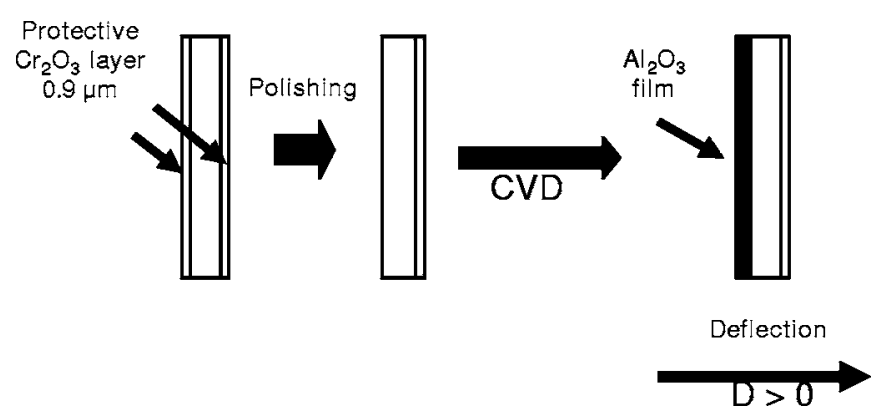

Figure 4. Schematic illustration of the configuration of the present samples after the various preparations.

with a TGDTA92 SETARAM thermobalance (sensitivity $\pm 1 \mu \mathrm{g}$ ). The results are illustrated in the mass gain vs time diagram of Fig. 3. Initial oxidation at $1123 \mathrm{~K}$ (curve a) leads to the development of the oxide scale. Corresponding weight gain follows a parabolic law with a parabolic rate constant whose value is compatible with those reported in Ref. 8 and 9. Subsequent maintainence at $1173 \mathrm{~K}$ in $\mathrm{Ar}$ (curve b), i.e., the maximum reached temperature and the corresponding atmosphere during deflection experiments, revealed neither weight gain nor spalling of the sample. Based on these results, a $0.9 \mu \mathrm{m}$ thick $\mathrm{Cr}_{2} \mathrm{O}_{3}$ layer was developed by oxidizing the substrate at $1123 \mathrm{~K}$ for $10 \mathrm{~h}$ in air, followed by removing the layer from one side of the sample by polishing.

The MOCVD process for the deposition of alumina was described in Ref. 5. It will be recalled here that deposition was performed from aluminium tri-isopropoxide in a horizontal hot-wall reactor with internal diameter of $26 \mathrm{~mm}$. Deposition temperature and pressure were $823 \mathrm{~K}$, and $2000 \mathrm{~Pa}$, respectively, and 99.9999\% pure nitrogen was used as a carrier gas. These conditions yield porous free, carbon free and hydroxyl free groups, amorphous, $1 \mu \mathrm{m}$ thick alumina layers. A detailed description of the characteristics of the obtained films will be presented in a forthcoming paper.

Figure 4 schematically illustrates the configuration of the present samples after the various preparations. These concern the development of the $\mathrm{Cr}_{2} \mathrm{O}_{3}$ protective film on both sides followed by polishing and deposition of alumina on the left side. During anisothermal treatments, generation of stresses will occur due to the differences between the thermal expansion coefficient of the protective film and the alumina film. For example, assuming that the two oxides $\left(\mathrm{Al}_{2} \mathrm{O}_{3}\right.$ and $\mathrm{Cr}_{2} \mathrm{O}_{3}$ ) have a similar thickness, if $\mathrm{Al}_{2} \mathrm{O}_{3}$ has a greater thermal expansion coefficient than $\mathrm{Cr}_{2} \mathrm{O}_{3}$, during heating the sample will be deflected toward the right side (positive deflection). In the present case, deflection tests were performed in $99.999 \%$ Ar, at a heating rate of $1200 \mathrm{~K} / \mathrm{h}$ up to $493 \mathrm{~K}$ followed by $100 \mathrm{~K} / \mathrm{h}$ up to $1173 \mathrm{~K}$. Such experiments present a greater sensitivity than elongation ones, namely a reproducibility with uncertainty on $D$ values equal to $\pm 0.005 \mathrm{~mm}$.

The microstructure of the as-developed protective films and of the MOCVD deposited alumina films at different steps of the deflection process was observed with a LEICA 260 scanning electron microscope (SEM) equipped with a Tracor Noran energy dispersive $\mathrm{X}$-ray spectrometer (EDXS). On various selected areas, the quantitative elemental analysis was performed using the matrix correction program ZAF. Grazing incidence $\left(\Omega=2^{\circ}\right)$ X-ray diffraction (XRD) was performed with a Seifert 3000 TT diffractometer, using monochromatized $\mathrm{Cu} \mathrm{K} \alpha$ radiation. This allowed investigation of the structure of the as-deposited and after heat-treatments alumina films.

\section{Results}

Figure 5 presents two surface SEM micrographs of the $\mathrm{Al}_{2} \mathrm{O}_{3}$ film before and after the deflection cycle. The as-deposited film is homogeneous and covers the entire coupon surface, without cracks or spallation. Its integrity is maintained after deflection. However, a 


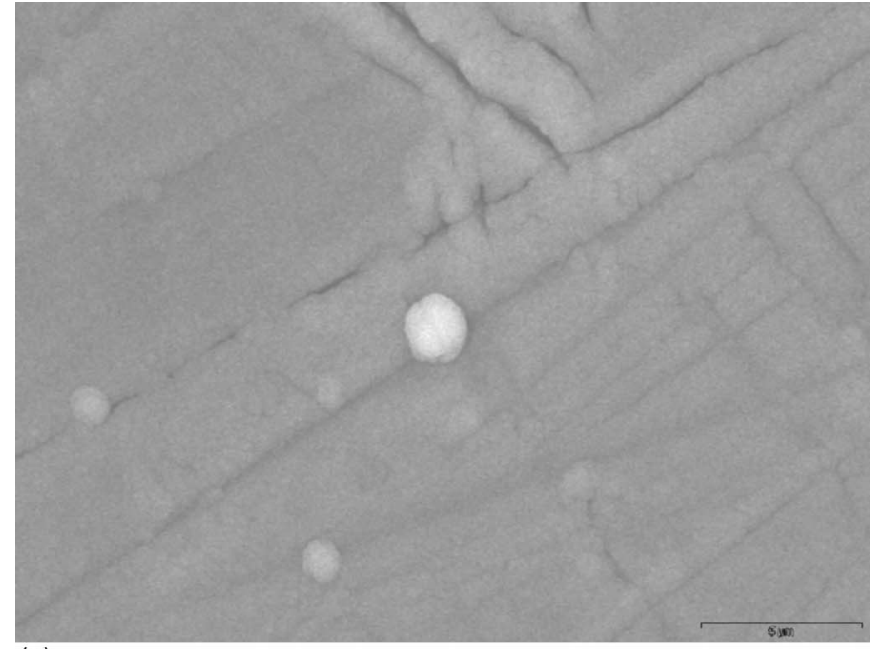

(a)

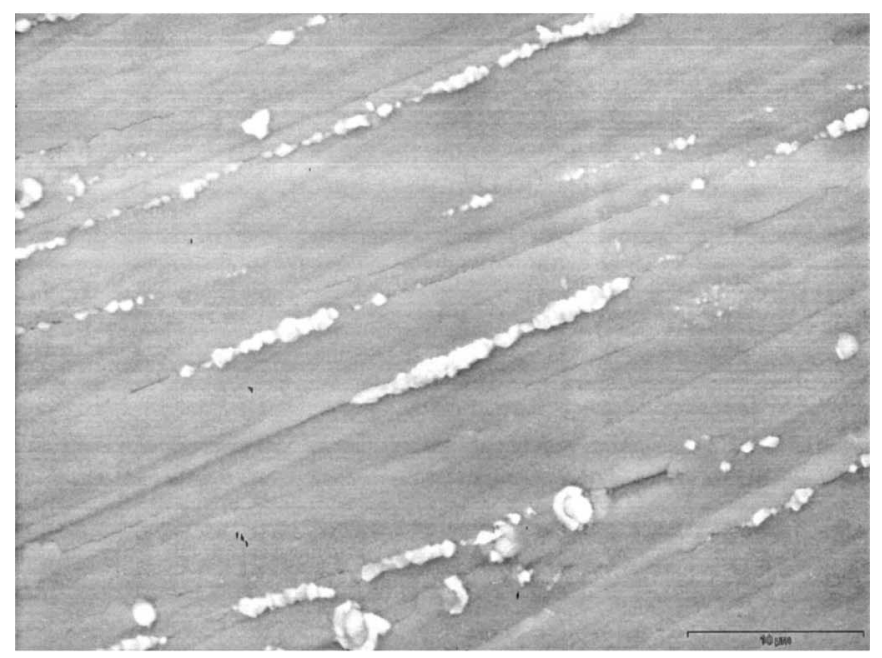

(b)

Figure 5. SEM images of the surface of $\mathrm{Al}_{2} \mathrm{O}_{3}$ film (a) before and (b) after the deflection cycle.

new phase is locally formed on the surface, illustrated in the micrograph by the bright grains which have grown over some stripes of the $\mathrm{Al}_{2} \mathrm{O}_{3}$ surface. Manganese was detected in this phase revealing that this element diffuses from the substrate through the film and forms Mn-rich oxide islands on the surface.

To evidence deflection results exclusively associated with the evolution of the alumina film, it was necessary to suppress, from the experimental curves obtained on $\mathrm{Al}_{2} \mathrm{O}_{3} / \mathrm{AISI} 301 / \mathrm{Cr}_{2} \mathrm{O}_{3}$ systems, the contribution associated with the evolution of the protective $\mathrm{Cr}_{2} \mathrm{O}_{3}$ film due its thermal expansion. This contribution is illustrated in the deflection vs temperature diagram of Fig. 6 for two different conditions. In the first (circles), deflection was performed on one sample for which one great face was covered with $\mathrm{Cr}_{2} \mathrm{O}_{3}$, while the other one was bare. Up to $773 \mathrm{~K}$, the obtained curve presented a positive deflection. This is attributed to the fact that the thermal expansion of the $\mathrm{Cr}_{2} \mathrm{O}_{3}$ film is smaller than that of the steel, generating tensile stresses in the chromia film. A negative deviation is observed from 773 to $1173 \mathrm{~K}$ revealing that oxygen impurities in the setup were sufficient to oxidize the bare face of the 301 steel. This situation does not prevail in the $\mathrm{Al}_{2} \mathrm{O}_{3} / 301 / \mathrm{Cr}_{2} \mathrm{O}_{3}$ system because the other face of the steel is covered with $\mathrm{Al}_{2} \mathrm{O}_{3}$ which prevents the substrate from oxidation. Consequently, such a sample is not representative of a correct reference state. To reliably reproduce the contribution associated with the evolution of the $\mathrm{Cr}_{2} \mathrm{O}_{3}$ film due to its thermal

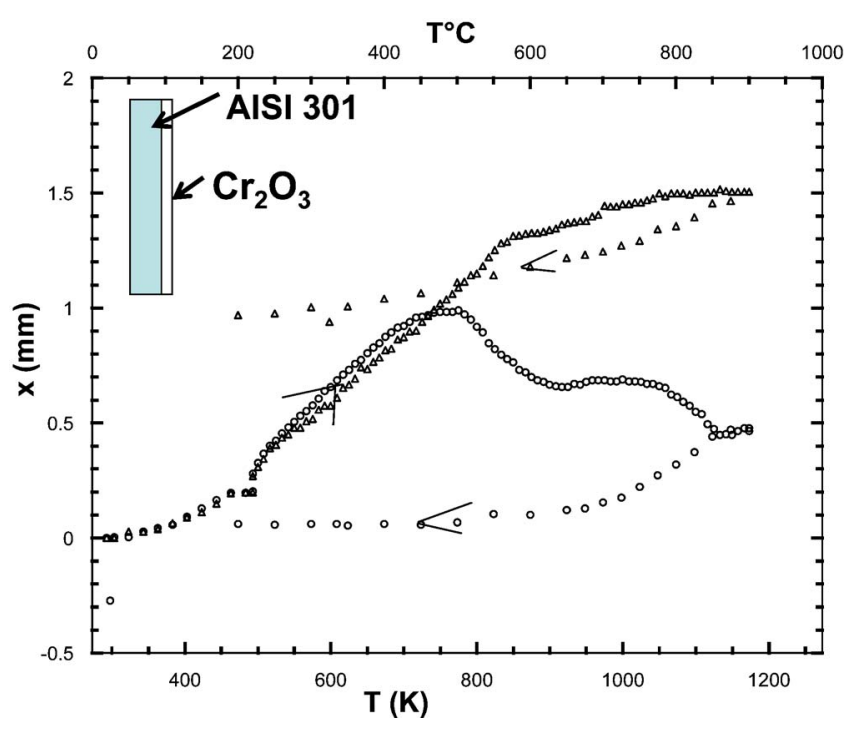

Figure 6. (Color online) Deflection cycle of the reference sample in two configurations: After removal of $\mathrm{Cr}_{2} \mathrm{O}_{3}$ from one side of the substrate (circles), and after removal of $\mathrm{Cr}_{2} \mathrm{O}_{3}$ from one side of the substrate followed by $5 \mathrm{~min}$ isothermal maintain in the MOCVD reactor in conditions of $\mathrm{Al}_{2} \mathrm{O}_{3}$ deposition but without flowing the precursor in the setup (triangles).

expansion, a sample for which one great face was covered with $\mathrm{Cr}_{2} \mathrm{O}_{3}$ was placed in the MOCVD reactor. Then, it was subjected to the same conditions as those used for the $\mathrm{Al}_{2} \mathrm{O}_{3}$ deposition, but by-passing the precursor bubbler, and was maintained only for $5 \mathrm{~min}$ in the temperature corresponding to the MOCVD process. This duration roughly corresponds to the incubation time in these conditions, prior initiation of the deposition of the $\mathrm{Al}_{2} \mathrm{O}_{3}$ film. The so-obtained data are illustrated in Fig. 6 by the triangles. These corresponding values of deflection will be systematically subtracted from the deflection curves obtained on the $\mathrm{Al}_{2} \mathrm{O}_{3} / 301 / \mathrm{Cr}_{2} \mathrm{O}_{3}$ system for each temperature.

Figure 7 presents the as-obtained deflection curve of the $\mathrm{Al}_{2} \mathrm{O}_{3} / 301 / \mathrm{Cr}_{2} \mathrm{O}_{3}$ system. It was checked that this result is reproducible by performing the same deflection experiment on two different samples obtained in the same conditions. In addition, the system is not subjected to ageing at room temperature as a deflection experiment performed six months after processing of the sample

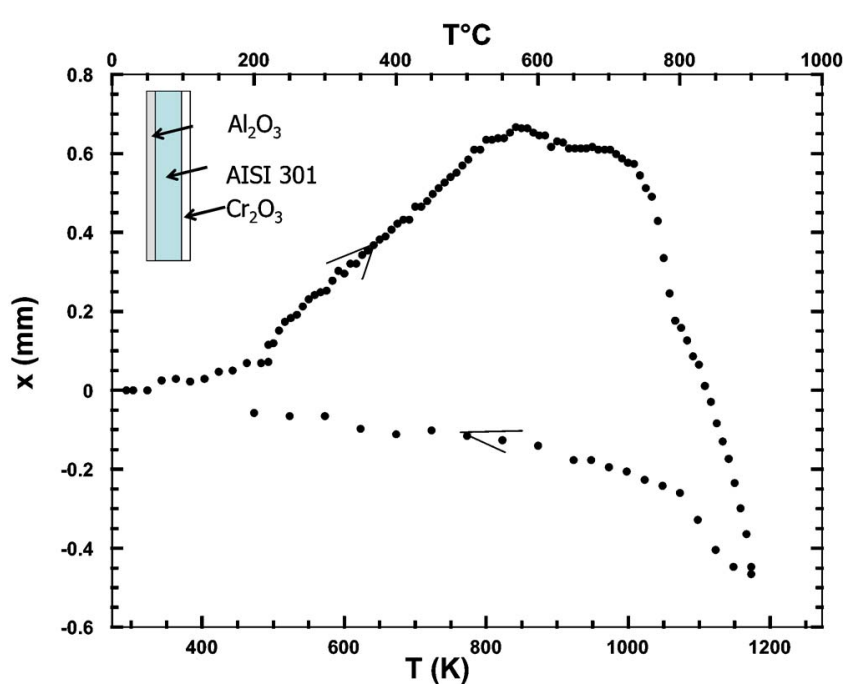

Figure 7. (Color online) As-obtained deflection curve of the $\mathrm{Al}_{2} \mathrm{O}_{3} / 301 / \mathrm{Cr}_{2} \mathrm{O}_{3}$ system 


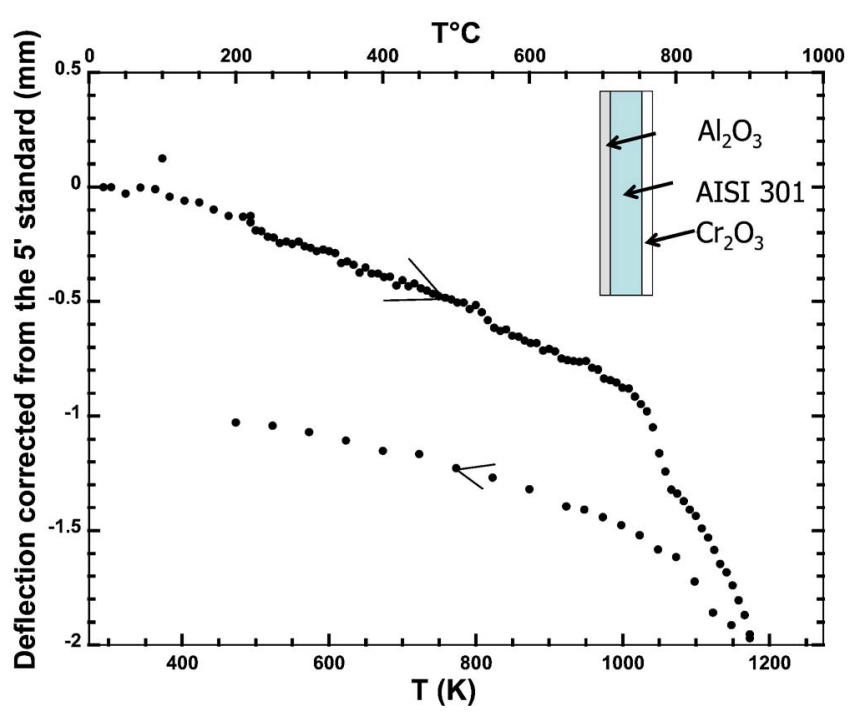

Figure 8. (Color online) Deflection curve of the $\mathrm{Al}_{2} \mathrm{O}_{3} / 301 / \mathrm{Cr}_{2} \mathrm{O}_{3}$ system after subtraction of the contribution associated with the evolution of the $\mathrm{Cr}_{2} \mathrm{O}_{3}$ film (triangles in Fig. 6).

yielded similar results. The diagram reveals that, up to $823 \mathrm{~K}$, i.e., the processing temperature of the film, a positive deflection takes place. This behavior corresponds to a thermal expansion coefficient of amorphous $\mathrm{Al}_{2} \mathrm{O}_{3}$ higher than that of $\mathrm{Cr}_{2} \mathrm{O}_{3}$. Above $823 \mathrm{~K}$, the increase of deflection stops and particular points are observed with a deflection decrease which accelerates when the temperature reaches $973 \mathrm{~K}$. During cooling, a more linear behavior is obtained probably corresponding to the differences in thermal expansion coefficients between $\mathrm{Cr}_{2} \mathrm{O}_{3}$ and $\mathrm{Al}_{2} \mathrm{O}_{3}$. The deflection diagram of Fig. 8 recalls the data presented in Fig. 7 but after subtraction of the contribution associated with the evolution of the $\mathrm{Cr}_{2} \mathrm{O}_{3}$ film (triangles in Fig. 6). The illustrated behavior is now exclusively attributed to the evolution of the $\mathrm{Al}_{2} \mathrm{O}_{3}$ film.

The XRD diagram of the $\mathrm{Al}_{2} \mathrm{O}_{3}$ coating at the end of the deflection cycle is presented at the upper part of Fig. 9. In agreement with the singular points observed in the deflection curves, transformation of the amorphous film clearly takes place yielding crystallized alumina peaks. The presence of three species corresponding to transition aluminas, $\gamma, \delta$, and $\theta$, is visible, and presence of the $\alpha$ phase is suggested. To access the nature of the phases which are formed at the particular points of the deflection curve, $\mathrm{Al}_{2} \mathrm{O}_{3}$ films were pro- cessed on AISI 301 in the same conditions as for the sample which underwent the deflection experiment and subjected to annealing in similar to the deflection treatments conditions by heating at 983 , 1043,1063 , and $1083 \mathrm{~K}$. The results of the XRD analysis of these samples are also reported in Fig. 9. It can be observed that crystallization is initiated at $983 \mathrm{~K}$ and is strongly enhanced at $1043 \mathrm{~K}$. It is possible that different transition aluminas are simultaneously formed at these temperatures, although unambiguous identification of phases is difficult from these diagrams.

\section{Discussion}

Thermal expansion of $\mathrm{Cr}_{2} \mathrm{O}_{3}$. - The behavior of the reference samples illustrated in Fig. 6 can be associated with the evolution of the oxidation kinetics of the bare face of the AISI 301 substrate in a second stage. But, in a first stage, the similar trends observed for the two curves up to $823 \mathrm{~K}$ indicate that, even if a $\mathrm{Cr}_{2} \mathrm{O}_{3}$ film is growing on the substrate, its thickness up to this temperature is negligible compared with that of the already grown $\mathrm{Cr}_{2} \mathrm{O}_{3}$ film on the other face, which is $0.9 \mu \mathrm{m}$. In such conditions, the positive deflection reveals the fact that the thermal expansion of the protective chromia film is lower than the thermal expansion of the steel, thus yielding tensile stresses in $\mathrm{Cr}_{2} \mathrm{O}_{3}$. The observed deflection in this temperature range allows determining the coefficient of thermal expansion (CTE) of the $\mathrm{Cr}_{2} \mathrm{O}_{3}$ film provided that of the steel is known. The stress $\sigma_{\mathrm{f}}$ in the $\mathrm{Cr}_{2} \mathrm{O}_{3}$ film is given by ${ }^{10}$

$$
\sigma_{\mathrm{f}}=D \frac{E_{\mathrm{m}}}{1-v_{\mathrm{m}}^{2}} \frac{e_{\mathrm{m}}^{2}}{3 e_{f} L^{2}}
$$

where $E_{\mathrm{m}}(193 \mathrm{GPa})$ and $\nu_{\mathrm{m}}(0.3)$ are the Young modulus and the Poisson coefficient of the metallic substrate, respectively, and $e_{\mathrm{m}}$ $(0.2 \mathrm{~mm})$ and $e_{\mathrm{f}}(0.9 \mu \mathrm{m})$ are the thickness of the metal and oxide film, respectively. The elastic thermal stresses in a thin oxide film applied on a thick metal substrate can be calculated by ${ }^{7,11,12}$

$$
\sigma_{\mathrm{f}}=-\int_{\text {To }}^{\mathrm{Ti}} \frac{E_{\mathrm{f}}\left(\alpha_{\mathrm{f}}-\alpha_{\mathrm{m}}\right)}{\left(1-v_{\mathrm{f}}\right)} d T
$$

where $E_{\mathrm{f}}\left(290 \mathrm{GPa}\right.$, average values for $\mathrm{Cr}_{2} \mathrm{O}_{3}$ from literature data ${ }^{12}$ ) and $v_{\mathrm{f}}(0.28)$ are the Young modulus and the Poisson coefficient of the oxide, respectively and $\alpha_{\mathrm{m}}$ is the CTE of AISI 301 (18.6 $\times 10^{-6} \mathrm{~K}^{-1}$ between 293 and $873 \mathrm{~K}$ ). This relation can be simplified to $\left|\sigma_{\mathrm{f}}\right|=E_{\mathrm{f}} \Delta \alpha \Delta T$, to calculate an average expansion coefficient. Then, the CTE of $\mathrm{Cr}_{2} \mathrm{O}_{3}$ is obtained from the deflection $D$ reached at $823 \mathrm{~K}(1.28 \mathrm{~mm})$ and is found to be equal to $7 \times 10^{-6} \mathrm{~K}^{-1}$. This value is of the same order of magnitude as values provided in the literature for $\mathrm{Cr}_{2} \mathrm{O}_{3}$, i.e., between $5.7 \times 10^{-6} \mathrm{~K}^{-1}$ and 9.6

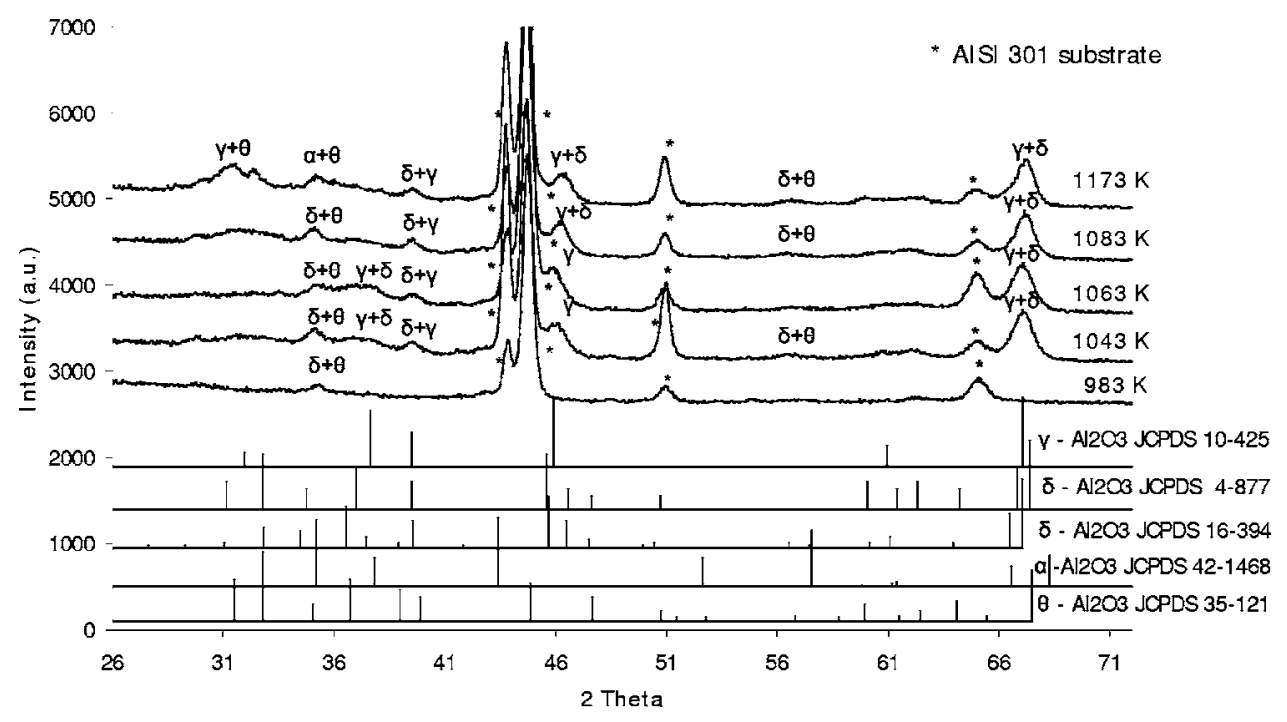

Figure 9. XRD patterns of the sample after the deflection cycle (upper diagram) and after similar heat-treatments up to the indicated temperatures. 


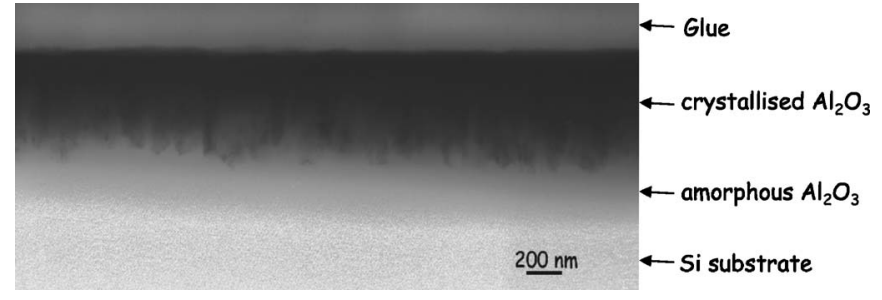

Figure 10. Transmission electron microscope (TEM) image of a thin film of alumina which was amorphous in the as-grown state (deposition temperature $753 \mathrm{~K}$ ) and which was partly crystallized by annealing at $1073 \mathrm{~K}$ for $3 \mathrm{~h}$.

$\times 10^{-6} \mathrm{~K}^{-1}$ according to different authors. ${ }^{12,13}$ Nevertheless, it is smaller than the value of $10.75 \times 10^{-6} \mathrm{~K}^{-1}$ recently proposed by other authors for $\mathrm{Cr}_{2} \mathrm{O}_{3}$ films, both by deflection and Raman spectroscopy experiments. ${ }^{10}$ Such results indicate that characteristics of the oxide films can vary according to the nature of the substrate, possibly on account of differences in the epitaxial relationships, yielding differences in the anisotropy of the film.

The deviation in the opposite direction which is observed above $823 \mathrm{~K}$, leading to the decrease and even to the inversion of the preliminary deviation, is attributed to the accelerated oxidation of the bare face of the AISI 301 when temperature increases. Such an oxidation leads to a progressively symmetrical system and the deviation is progressively reduced.

Thermal expansion and phase transformations of $\mathrm{Al}_{2} \mathrm{O}_{3}$.- Taking into account that the $\mathrm{Al}_{2} \mathrm{O}_{3}$ and the $\mathrm{Cr}_{2} \mathrm{O}_{3}$ films have fairly the same thickness, in the temperature range where no transformation occurs in $\mathrm{Al}_{2} \mathrm{O}_{3}$ (i.e., up to a deposition temperature of $823 \mathrm{~K}$ ), the resulting deflection during heating illustrated in Fig. 7 is expected to be proportional to the difference between the CTEs of these two oxide films. The observed positive deflection during heating up to $823 \mathrm{~K}$ indicates that alumina has a greater thermal expansion coefficient than chromia, which is in agreement with literature data. ${ }^{12,14}$ Calculations taking the previous value of CTE for $\mathrm{Cr}_{2} \mathrm{O}_{3}$ expansion coefficient $\left(7 \times 10^{-6} \mathrm{~K}^{-1}\right), 390 \mathrm{GPa}$, and 0.25 for the Young modulus and the Poisson coefficient of $\mathrm{Al}_{2} \mathrm{O}_{3}$, respectively, leads to $\alpha_{\mathrm{Al} 2 \mathrm{O} 3}=14.7 \times 10^{-6} \mathrm{~K}^{-1}$. This value is somewhat greater than that recently determined for $\mathrm{Al}_{2} \mathrm{O}_{3}$ grown on an ODS $\mathrm{FeCrAl}$ alloy (PM2000), i.e., $10.3 \cdot 10^{-6} \mathrm{~K}^{-1} .{ }^{14}$ Note, however, that the latter value concerns $\alpha-\mathrm{Al}_{2} \mathrm{O}_{3}$, to be compared with the MOCVD processed amorphous $\mathrm{Al}_{2} \mathrm{O}_{3}$ of the present study.

The negative deflection observed in Fig. 8 for the $\mathrm{Al}_{2} \mathrm{O}_{3}$ film between the ambient and the processing temperature is attributed to the lower CTE of the amorphous $\mathrm{Al}_{2} \mathrm{O}_{3}$ than that of the AISI 301, namely $14.7 \times 10^{-6} \mathrm{~K}^{-1}$ to be compared with $18.6 \times 10^{-6} \mathrm{~K}^{-1}$. The significant modification of the slope yielding a more negative deflection which is observed above ca. $983 \mathrm{~K}$ is attributed to the onset of the crystallization of the $\mathrm{Al}_{2} \mathrm{O}_{3}$ phase. Crystallization induces a decrease of the volume of the film through the modification of its volumic mass which is increased from $3.40 \mathrm{~g} / \mathrm{cm}^{3}$ for the amorphous $\mathrm{Al}_{2} \mathrm{O}_{3}$ to ca. $3.63-3.66 \mathrm{~g} / \mathrm{cm}^{3}$ for $\gamma-, \delta-$, and $\theta$ $-\mathrm{Al}_{2} \mathrm{O}_{3}$ and finally to $3.99 \mathrm{~g} / \mathrm{cm}^{3}$ for $\alpha-\mathrm{Al}_{2} \mathrm{O}_{3}$. The onset of the crystallization of the amorphous to transition $\mathrm{Al}_{2} \mathrm{O}_{3}$, especially to the $\gamma$ phase above ca. $983 \mathrm{~K}$, is confirmed by the XRD patterns and has been illustrated by TEM analysis, as shown in Fig. 10 .

This transformation occurs gradually between ca. 983 and $1063 \mathrm{~K}$ and for this reason the slope of the deflection becomes steeper from 983 to $1063 \mathrm{~K}$. The singular point observed at ca. $1063 \mathrm{~K}$ is attributed to a particular phase transformation which is initiated at this temperature. Comparison between XRD patterns of $\mathrm{Al}_{2} \mathrm{O}_{3}$ films after annealing at $1083 \mathrm{~K}$ or after annealing at $1173 \mathrm{~K}$ and also after a complete deflection cycle (Fig. 9) reveals that a noticeable modification of the patterns occur in the $2 \theta 30^{\circ}$ and $40^{\circ}$. Although identification of the peaks in this range is not straightfor- ward, crystallization of $\alpha-\mathrm{Al}_{2} \mathrm{O}_{3}$ can be identified. However, such a short heat-treatment without maintaining the sample at $1173 \mathrm{~K}$ for a long time period is not enough for the extended transformation of the film to $\alpha-\mathrm{Al}_{2} \mathrm{O}_{3}$. Indeed, it has been reported ${ }^{14}$ that to maintain the heat-treatment for $18 \mathrm{~h}$ at $1173 \mathrm{~K}$ is necessary for the transition to $\alpha-\mathrm{Al}_{2} \mathrm{O}_{3}$ of the thermally grown $\mathrm{Al}_{2} \mathrm{O}_{3}$ on a $\mathrm{FeCrAl}$ alloy.

\section{Conclusions}

Anisotherm deflection experiments, associated with grazing XRD and SEM, were used here to investigate the microstructural evolution of MOCVD processed $\mathrm{Al}_{2} \mathrm{O}_{3}$ films from aluminium triisopropoxide, on one side of AISI 301 coupons. With the aim to prepare dissymmetrical samples for the deflection tests, a thermally grown $\mathrm{Cr}_{2} \mathrm{O}_{3}$ film was developed on the steel by subjecting it to a heat-treatment at $1123 \mathrm{~K}$ in air followed by polishing of one side prior deposition of $\mathrm{Al}_{2} \mathrm{O}_{3}$. It was verified that $\mathrm{Cr}_{2} \mathrm{O}_{3}$ remains stable during the subsequent treatments and that deflection did not yield any cracks or spalling of the $\mathrm{Al}_{2} \mathrm{O}_{3}$ film which would have altered its strain-stress state and modified its behavior.

Deflection experiments allowed determining the CTE of both the protective chromia film and the alumina MOCVD films. The CTE of the thermally grown $\mathrm{Cr}_{2} \mathrm{O}_{3}$ film was found to be $7 \times 10^{-6} \mathrm{~K}^{-1}$. This value is comparable with those provided in the literature but is lower than that of thermally grown $\mathrm{Cr}_{2} \mathrm{O}_{3}$ films on ferritic $\mathrm{Fe}-18 \mathrm{Cr}-\mathrm{TiNb}$ stainless steel probably on account of different growth orientation of the film. CTE of the as deposited amorphous $\mathrm{Al}_{2} \mathrm{O}_{3}$ film was found to be equal to $14.7 \times 10^{-6} \mathrm{~K}^{-1}$ which is a higher value than that of crystallized $\mathrm{Al}_{2} \mathrm{O}_{3}$.

Detection of phase transformation of the amorphous to crystalline $\mathrm{Al}_{2} \mathrm{O}_{3}$ was investigated. It was shown that crystallization kinetics become significant at temperatures equal or greater than $983 \mathrm{~K}$. At this temperature, initiation of the formation of metastable $\mathrm{Al}_{2} \mathrm{O}_{3}$ mainly composed of $\gamma-\mathrm{Al}_{2} \mathrm{O}_{3}$, is observed. Transformation of metastable to $\alpha-\mathrm{Al}_{2} \mathrm{O}_{3}$ is initiated perhaps as soon as $1083 \mathrm{~K}$ but is observed by XRD diffraction only at $1173 \mathrm{~K}$. These results are in agreement with the literature and with ongoing investigation of the phase transformations of MOCVD processed $\mathrm{Al}_{2} \mathrm{O}_{3}$ by classical characterization techniques.

It is demonstrated that deflection is a powerful tool to investigate the behavior of thin films deposited on a substrate and especially to reveal transformations occurring in these films during heattreatments.

\section{Acknowledgments}

This work is part of the Ph.D. thesis of M.M.S. at Universitatea Politehnica din Bucuresti and at Institut National Polytechnique de Toulouse. M.M.S. acknowledges the Romanian government for a study grant. We are indebted to D. Sadowski for technical support, and to M.C. Lafont for TEM analyses.

The Université d'Orsay and the Centre Interuniversitaire de Recherche et d'Ingénierie des Matériaux assisted in meeting the publication costs of this article.

\section{References}

1. S. Blittersdorf, N. Bahlawane, K. Kohse-Höinghaus, B. Atakan, and J. Müller, Chem. Vap. Deposition, 9, 194 (2003).

2. V. A. C. Haanappel, H. D. van Corbach, R. Hofman, R. W. J. Morssinkhof, T Fransen, and P. J. Gellings, High Temp. Mater. Processes (N.Y., NY, U.S.), 15, 245 (1996).

3. S. S. Yom, W. N. Kang, Y. S. Yoon, J. I. Lee, D. J. Choi, T. W. Kim, K. Y. Seo, P. H. Hur, and C. Y. Kim, Thin Solid Films, 213, 72 (1992).

4. A. Gleizes, C. Vahlas, M.-M. Sovar, D. Samélor, and M.-C. Lafont, Chem. Vap. Deposition, Submitted.

5. D. Samélor, M.-M. Sovar, A. Stefanescu, A. N. Gleizes, P. Alphonse, and C. Vahlas, in Fifteenth European Conference on Chemical Vapor Deposition EUROCVD-15, A. Devi, R. Fischer, W. Parala, M. D. Allendorf, and M. Hitchmer Editors, PV 2005-09, p. 1051, The Electrochemical Society Proceedings Series, Pennington, NJ (2005). 
6. B. Castel, Les Alumines et Leurs Applications, Aluminium Pechiney-TechnoNathan, Paris (1990).

7. A.-M. Huntz, G. Calvarin Amiri, H. E. Evans, and G. Cailletaud, Oxid. Met., 57, 499 (2002).

8. A. Atkinson, Rev. Mod. Phys., 57, 437 (1985).

9. A. C. S. Sabioni, A. M. Huntz, E. C. Luz, M. Mantel, and C. Haut, Mater. Res., 6, 179 (2003).

10. J. Mougin, A. Galerie, M. Dupeux, N. Rosman, G. Lucazeau, A.-M. Huntz, and L.
Antoni, Mater. Corros., 53, 486 (2002).

11. A. Galerie, F. Toscan, M. Dupeux, J. Mougin, G. Lucazeau, C. Valot, A.-M. Huntz, and L. Antoni, Mater. Res., 7, 81 (2004).

12. M. Schütze, Protective Oxide Scales and Their Breakdown, John Wiley \& Sons, Chichester, UK (1991)

13. A.-M. Huntz, Mater. Sci. Eng., A, 201, 211 (1995).

14. A.-M. Huntz, L. Maréchal, B. Lesage, and R. Molins, Appl. Surf. Sci., 252, 778 (2006). 